\title{
EDITORIAL
}

\section{MAYORES EN PANDEMIA: RESISTENCIA NUMANTINA}

\author{
J. Javier Soldevilla Agreda \\ Director Gerokomos
}

Ha pasado ya un largo año de asedio.

Las cifras de contagiados, muertos y muy damnificados entre las tropas de personas mayores en estos meses de asoladora pandemia, al son de lamentos y quebranto deben escribir un episodio histórico para el futuro que muestre su debilidad al tiempo que su coraje, su sacrificio y especialmente su resistencia ante vicisitudes que pocas veces antes con tanta belicosidad habíamos vivido en la era moderna.

Escipión, en el año 134 a.C., a instancias del imperio de Roma tomó posiciones frente a Numancia, enclave muy próximo a la actual ciudad de Soria, construyendo fosos, empalizadas, desniveles y muros de protección, sitiando ese reducto sin pelear directamente con ese puñado de ciudadanos, concibiendo un plan de guerra consistente en mermar sus fuerzas hasta que los habitantes se rindieran.

Pocos días de asedio y el hambre venció a la ciudad. Sus habitantes prefirieron el suicidio a entregarse. Incendiaron la ciudad para que no cayera en manos de los romanos. Los pocos supervivientes fueron vendidos como esclavos. Numancia pasó a la leyenda.

Ha trascendido a la historia la impresionante actitud de los numantinos convirtiéndose en un mito e incluso taladrando nuestro rico idioma, como reza en la RAE el adjetivo "numantino" como el que "resiste con tenacidad hasta el límite, a menudo en condiciones precarias".

Con este retazo histórico en la memoria y la reciente hecatombe epidemiológica y social, configuramos un escenario novelesco con variante a lo acontecido en el cerro de Numancia. Un desconocido virus transportado en ingenuos o ignorantes caballos de Troya lograron burlar las generalmente endebles fortificaciones establecidas entre muchos mayores en sus refugios domiciliarios, pero especialmente los que vivían en instituciones. Una vida interior, con habitantes de fuerzas mermadas, sostenida a menudo por exiguas huestes de cuidadores con vocación intachable, pero formación bélica-sanitaria y recursos insuficientes, ante un enemigo tan virulento creciente en el exterior, consumiendo los recursos defensivos, pero también colándose en el interior de esas fortalezas. A diferencia de esos pobladores celtíberos en la Castilla profunda, el enemigo estaba dentro, las provisiones escaseando, la ayuda que llegaba a través de la muralla, al principio, desordenadamente testimonial y, además, no "dejaban salir a los heridos".
La permisividad que ofrece un relato ficticio aun alojado en una tribuna científica como esta quiere en esta ocasión poner de manifiesto una circunstancia con suficientes aristas para la reflexión y la acción de la ciudadanía en general y de los responsables custodios de estas personas cercadas.

Las personas mayores han dado demostración de resistencia numantina como ningún otro grupo. Han vivido y sufrido el mayor de los aislamientos estoicamente, con miedo, pero con gallardía, y aunque ha habido muchas bajas, victoriosos de momento ante el terror. El enemigo no ha huido, ni mucho menos ha sido vencido, está retirado en sus castillos de invierno y lamentablemente se reagrupará para volver y por eso requiere, en este tiempo de moderada tregua, de una acción defensiva que no vuelva a sorprender y matar con tanta sańa hasta que se reconstruya desde los cimientos la fortaleza.

Se ha recuperado el pulso a la llegada de material de primera línea, de escudos sanitarios con medidas ensayadas (la vacuna), cribados masivos de invasores e invadidos, de revocación de decisiones que impedían la llegada de aliados, que parecen no existir en cuantía suficiente, pero tampoco de evacuar en un pasillo blindado a personas para recibir merecida ayuda fuera de la empalizada. Hemos aprendido que en esas paredes asediadas se encuentra nuestra historia, nuestro legado, un tesoro que custodiar y que quizá no lo estaba siendo como merecía. Evidenciadas las carencias, solo la valentía de los habitantes de esas "ciudades de mayores", abnegación de sus fieles cuidadores, queda por tejer un plan que remiende las debilidades de este sistema sociosanitario permisivo y en aspectos de cartón-piedra, de almacenar recursos que puedan atender realmente las necesidades de esos canónigos de vida conventual de nuestra sociedad en su esfera humanística pero también, ante su vulnerabilidad y frecuente cronicidad, en esmerada atención sanitaria. Es necesario un plan estratégico que derribe ese aislamiento y desatención. Es necesario visibilizar ahora, todavía embebidos en ese grito ahogado, la verdadera situación allende las almenas. Es necesario reconocer los cuidados como un bien público e invertir más, compromisos que lleven aparejados cambios e inversiones y, de esta historia, aprender y avanzar.

Se ha comprobado que el enemigo acertó eligiendo por su accesibilidad esas fortalezas de pobladores canos, pero como Roma, seguro sorprendidos por esta resiliencia y resistencia numantina. No los abandonemos nuevamente a su suerte 